\title{
Impact of soil compaction on the engineering properties of potato tubers
}

\author{
Mohamed K. Edrris ${ }^{1 *}$, Khalid A. Al-Gaadi ${ }^{1,2}$, Abdalhaleem A. Hassaballa ${ }^{3}$, \\ EIKamil Tola ${ }^{1,2}$, Khalid A. M. Ahmed ${ }^{2,4}$ \\ (1. Precision Agriculture Research Chair, King Saud University, Riyadh 11451, Saudi Arabia; \\ 2. Department of Agricultural Engineering, College of Food and Agriculture Sciences, King Saud University, Riyadh 11451, Saudi Arabia; \\ 3. Department of Agricultural \& Biological Engineering, Faculty of Engineering, Khartoum University, Khartoum, Sudan; \\ 4. Chair of Dates Industry and Technology, King Saud University, Riyadh 11451, Saudi Arabia)
}

\begin{abstract}
A study on a $30 \mathrm{hm}^{2}$ field was conducted to assess the variability in soil compaction and to investigate its effect on the engineering properties of potato tubers in terms of tuber shape and key dimensions (length, width and thickness) and resistance to penetration, rupture and shear forces. Three soil compaction levels were spatially correlated with the engineering properties of potato tubers through linear regression and ANOVA test. The three compaction levels included a low level (C1) ranging between 1.2-1.9 $\mathrm{MPa}$, a medium level (C2) with compaction levels between 2.0-2.3 MPa and a high level (C3) ranging between 2.4-2.9 MPa. Results revealed that there were no significant changes in the key tuber dimensions corresponding to the variability in soil compaction. However, inverse linear relationships were observed between soil compaction and the key tuber dimensions with $\mathrm{R}^{2}$ values of $77 \%, 97 \%$ and $96 \%$ for length, width and thickness, respectively. Similarly, the soil compaction was shown to have no effect on the tuber resistance to compression and shear force. In contrast, the tuber resistance to penetration was significantly affected by soil compaction $(p>F=0.0012)$.
\end{abstract}

Keywords: compaction, potato tubers, precision agriculture, potato engineering properties

DOI: $10.25165 /$ j.ijabe.20201302.4818

Citation: Edrris M K, Al-Gaadi K A, Hassaballa A A, Tola E, Ahmed K A M. Impact of soil compaction on the engineering properties of potato tubers. Int J Agric \& Biol Eng, 2020; 13(2): 163-167.

\section{Introduction}

Soil compaction is generally defined as the increase in soil density mostly due to the pressure on the soil ${ }^{[1]}$. The existence of compacted layers of dense soil near the soil surface is often attributed to the use of heavy machinery or the cultivation of wet soils. Deep compacted layers; however, may be caused by heavy harvesting machinery or trailers at times when the soil is too wet to withstand these high axle loads. The need to plant crops over a limited time window may increase the risk of soil compaction when working in soil of an inappropriate condition. A certain degree of soil compaction is needed for crop growth, so that a good seed-soil contact can help stabilize the roots and improve water absorption. In contrast, a very low soil compaction around potato tubers at the planting time could delay crop emergence. The shallow rooting system of potatoes (about half of the effective rooting depth of cereals) makes them more sensitive to unfavorable soil conditions, such as low soil moisture and high soil compaction, compared to other crops ${ }^{[2]}$.

Under natural conditions, field soil physical properties were found to be of high horizontal and vertical spatial variability that

\section{Received date: $2018-12-03 \quad$ Accepted date: $2020-02-08$}

Biographies: Khalid A. Al-Gaadi, PhD, Professor, research interests: precision agriculture, Email: kgaadi@ksu.edu.sa; Abdalhaleem A. Hassaballa, PhD, Assistant Professor, research interests: precision agriculture, Email: ahassaballa@gmail.com; ElKamil Tola, PhD, Associate Professor, research interests: precision agriculture, Email: etola@ksu.edu.sa; Khalid A. M. Ahmed, $\mathrm{PhD}$, Assistant Professor, research interests: food manufacturing engineering, Email: kamahmed2000@gmail.com.

*Corresponding author: Mohamed K. Edrris, MSc, Researcher, research interests: precision agriculture. P.O. Box 2460, Riyadh 11451, Saudi Arabia. Tel: +966501484894, Email: medrris@ksu.edu.sa, mkedrris@gmail.com. can persist over time ${ }^{[3]}$. Therefore, there is an urgent need to study the spatiotemporal changes in soil properties, which introduces the need to use tools, such as geostatistics ${ }^{[4]}$. These tools allow study on the spatial and temporal distribution of soil properties, such as moisture and compaction ${ }^{[5]}$, which are critical factors in vegetation cover and land-use changes ${ }^{[6]}$. Changes in these soil attributes can principally affect some important properties, such as particle size, soil structure and hydraulic conductivity $^{[5]}$. Understanding the spatial variability of soil physicochemical characteristics in their dynamic forms (for example, compaction and water content) is necessary for site-specific management of agricultural practices, as they directly contribute to the variability in crop yield and quality ${ }^{[7]}$.

Soil compaction is an important factor deemed in soil degradation. This is manifested by a reduction in the volume of soil and an increase in its bulk density, which reduces soil porosity and influences the shape and size distribution of the soil pores ${ }^{[8]}$. In industrial and developing countries, potatoes are particularly important in the food chain among agricultural products. Potatoes contain an amount of energy equivalent to 830 calories per kilogram $^{[9]}$. There are some situations in which the determination of relationships among physical characteristics of agricultural products is necessary; for example, some fruits are graded by size ${ }^{[9]}$ Similarly, physical characteristics of agricultural products are the most important parameters for the design of grading, handling, processing and packaging systems, these physical characteristics include the mass, shape and volume, and the width, length and thickness $^{[10,11]}$

Understanding the mechanical characteristics of potato tubers may improve harvesting and handling equipment and reduce economic losses. In addition to size and shape, the texture of tubers is also an important factor in the technical classification of 
cultivars for potato chips and home use ${ }^{[12]}$. In fact, potato tubers are not formed on a single plant at the same time during the growing season, and the continuous tuber growth results in the production of tubers of different sizes at harvest. The large variations in the mechanical properties of potato tubers can be also attributed to the physiological characteristics of the tubers, such as size and shape ${ }^{[12]}$. However, the reason of varying degree of hardness within the tubers, associated with the structure of tissues for particular morphological elements of the tubers, is still undetermine $\mathrm{d}^{[12]}$. In the industry, the size (volume and diameter) is the most important parameter in classifying the fruit quality and is always a price determining factor ${ }^{[13]}$. In the non-destructive technologies, the volume is viewed as a key indicator for fruits ripeness. Hahn and Sanches ${ }^{[14]}$ used these technologies to predict the optimum harvest time, and Mitchell ${ }^{[15]}$ used them to predict the yield of products. Ngouajio et al. ${ }^{[16]}$ investigated the relationship between the rate of expansion and the susceptibility to physiological disorder, such as fruit cracking. Similarly, Safa and Khazaei $^{[17]}$ studied the physical properties of pomegranate and designed models for predicting fruit mass based on fruit dimensions, volume and surface area.

Most of the previous studies on soil compaction focused on cereal and forage crops rather than vegetables and fruits. Studies have shown that compacted soil has reduced the root size of peas, potatoes $^{[18]}$, soybeans ${ }^{[19]}$ and the fruit length/diameter ratio of cucumbers ${ }^{[20]}$. It was also reported that higher mechanical impedance resulted in thicker roots of potatoes ${ }^{[21]}$ and peas ${ }^{[22]}$. In general, soil compaction can influence yield by decreasing the quality, weight and size of fruits ${ }^{[20]}$.

Several studies focused on the accuracy and repeatability for the evaluation of potato tuber tissue hardness; however, standard parameters and conditions for determination of mechanical resistance are not commonly accepted. Numerous variants of small deformation tests ${ }^{[23]}$ have been proposed for the evaluation of the mechanical/textural parameters of raw and treated potato tubers.
The compression test has been used on a large scale to evaluate the mechanical behavior of stored potato tissue, and the expression "longitudinal stiffness" is used to characterize tissue stiffness as a whole, which has been shown to increase with both cell wall stiffness and cell turgor pressure ${ }^{[24]}$. Also, it was demonstrated that the stiffness of potato cell wall increased after the cell wall was plastically deformed.

Since soil compaction is considered as one of the most important factors in crop production systems, this study was designed to investigate the impact of soil compaction variability on selected engineering properties of potato tubers. These properties included key dimensions, shape, resistance to penetration, rupture and shear forces.

\section{Materials and methods}

\subsection{Experimental site}

The study was conducted on a $30 \mathrm{hm}^{2}$ (half-pivot size) field located in the property of the Agricultural Development Company in Wadi Al Dawasir area $740 \mathrm{~km}$ south of Riyadh, the capital city of Saudi Arabia. The soil of the study field was characterized as a sandy soil and the field was under potato (Spunta potatoes) cultivation during the period from November 2016 to March 2017. The climatic aspects of the study area were characterized by temperatures ranging from $6^{\circ} \mathrm{C}$ to $43^{\circ} \mathrm{C}$, a stable relative humidity of about $24 \%$, a solar radiation of average sunrise duration of $11 \mathrm{~h} / \mathrm{d}$, an average wind speed of $13 \mathrm{~km} / \mathrm{h}$ and up to $46 \mathrm{~km} / \mathrm{h}$ in thunder storm incidents and a mean annual rainfall of about $37.6 \mathrm{~mm}^{[25]}$.

\subsection{Sampling strategy}

The experimental field was sampled on $50 \mathrm{~m} \times 50 \mathrm{~m}$ grid cells producing 120 data points. Soil samples were collected, along with compaction measurements recorded at the center of each sampling grid cell, and georeferenced using a hand-held GPS receiver (Trimble GeoXH). Figure 1 show the study field overlaid by the sampling grid cells.

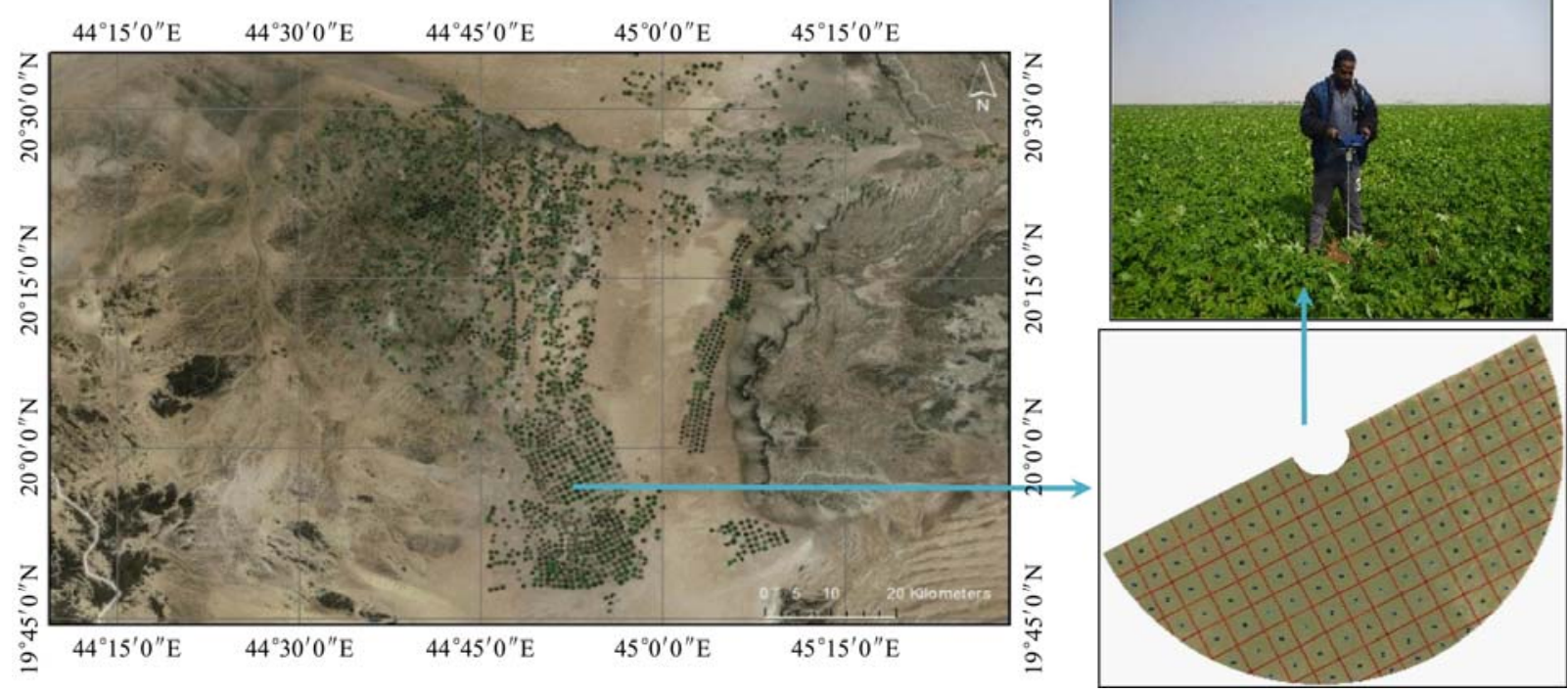

Figure 1 The study field overlaid by the sampling grid cells

Soil compaction was measured at the pre-determined field locations for four successive periods of field measurements using the handheld penetrologger (Eijkelkamp device with a $10 \mathrm{~mm}$ diameter and a cone angle of $60^{\circ}$ ). The penetrologger was equipped with a complete set suitable for measurements up to a depth of $80 \mathrm{~cm}$. Soil compaction measurements were achieved by pushing the penetrologger vertically into the soil at an approximate speed of $2 \mathrm{~cm} / \mathrm{s}$, as recommended by the device manufacturer ${ }^{[26]}$. Five soil compaction measurements surrounding each sampling point, at the depth of 0-30 $\mathrm{cm}$, were taken and then averaged out to represent that point. Compaction measurements (MPa) were conducted four times during the potato crop life span with a 
frequency of 40-45 d. During each compaction measurement, soil moisture samples were collected and analyzed in order to assess the soil status for compaction value rectification.

In-situ collection of potato yield samples was performed by harvesting the crop in an area of $3 \mathrm{~m}^{2}$ at each sampling point. The delineation of the collection area was performed using a measuring tape and flags, where small trowels were used for harvesting the potatoes within the delineated area. The collected potato samples were packed in small sacks, weighed and up-scaled to the ordinary yield unit $\left(\mathrm{t} / \mathrm{hm}^{2}\right)$.

\subsection{Engineering properties of potato tubers}

Collected potato tuber samples were analyzed at the laboratory for their shape, size, and resistance to penetration, shear and compression forces. All measurements were conducted at the laboratory of Food Engineering of the Department of Agricultural Engineering, College of Food and Agriculture Sciences, King Saud University.

\subsection{Potato tuber shape index}

Three mutually perpendicular axes of the potato tubers were measured with a digital Vernier caliper (Figure 2), where the tuber sample was set on a flat surface. The longest intercept $(L)$ represented the tuber length, the longest intercept $(W)$ perpendicular to $L$ represented the tuber width and the longest intercept $(T)$ perpendicular to $W$ and $L$ represented the tuber thickness ${ }^{[27]}$. Three randomized samples of potato tubers were carefully obtained at harvesting (fresh tubers) for the 120 points across the field. Hence, the shape index of the measured samples was calculated according to Ismail ${ }^{[28]}$, as in Equation (1):

$$
I=\frac{L}{\sqrt{T W}}
$$

where, $I$ is the shape index, $L$ is the potato tuber length, $\mathrm{mm} ; W$ is the tuber width, $\mathrm{mm}$; and $T$ is the tuber thickness, $\mathrm{mm}$.

The obtained index values were compared to the recommended limits and used to classify the tubers into two main classes (spherical and oval shapes). Tubers with $I<1.5$ were classified as spherical shaped; however, tubers with $I$ values of $\geq 1.5$ were categorized as oval shaped ${ }^{[29]}$.
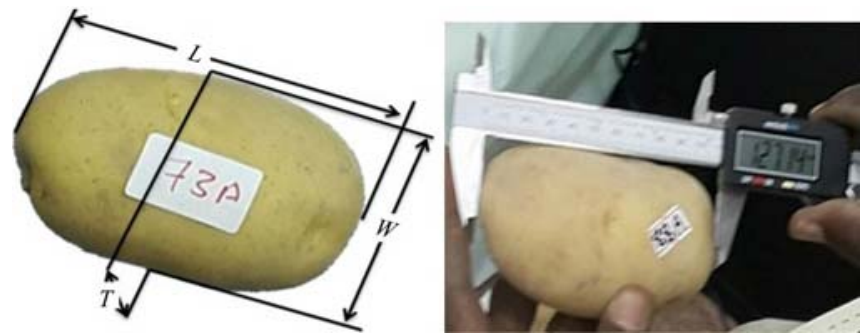

Figure 2 Three mutually perpendicular axes of potatoes

\subsection{Mechanical properties of potato tubers}

The mechanical property test device (Texture Analyzer TA-HDi, Model HD3128, Stable Micro Systems, Surrey, UK) used in this study was adaptable with many probes that have been used for tuber sample penetration test. The device was controlled by a computer software program (texture expert exceeds version 2.05) that can help in data analysis, depicts the relationships of distance with time and concludes some of mechanical characteristics.

\subsection{Compression test}

The compression tests of the tubers were conducted using the Texture Analyzer device that was equipped with a $55 \mathrm{~mm}$ (P75) plunger and a load cell of $250 \mathrm{kN}$ (Figure 3). The strength and deformation of the samples were measured using a $31 \mathrm{~mm}$ deep sample pulp. Different mechanical properties were calculated from distance and power relationships when the sample was compressed. The module of elasticity was estimated by calculating the straight line slope in a given section of the force-slope-distance through the flexible phase ${ }^{[30]}$. This is called the elasticity factor in a compression phase, which refers to the penetration module in a penetration stage. The rupture point, which is affected by the compression, depends on a number of factors, including the composition of the nutrient and the homogeneity of the tested sample. For this study, this test was intended to investigate the effect of soil compaction on the production of spatially variable potato tubers based on different structures and resistances.

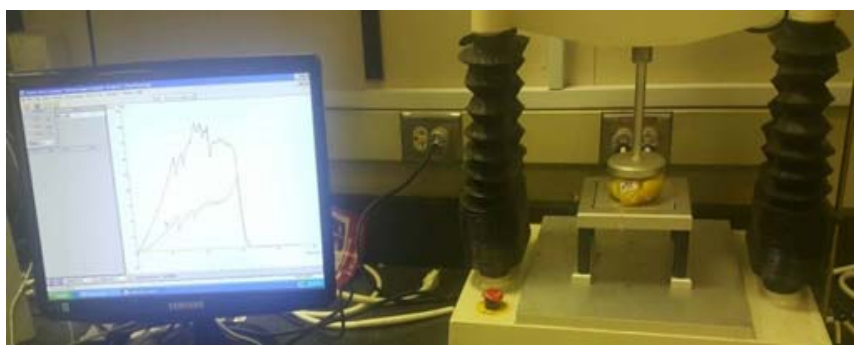

Figure 3 Compression test of potato tubers

\subsection{Penetration test}

A penetration test was applied on the potato tubers using a cylindrical penetration probe of $2.0 \mathrm{~mm}$ diameter to a depth of $10 \mathrm{~mm}$ from the tuber surface (Figure $4 \mathrm{a}$ ). This test was assumed to be important in order to determine the resistance of the potato crust to the occurrence of cracks when handled in production lines and packaging. In addition, the test was also important when estimating potato resistance to insect penetration.

\subsection{Shear test}

Potato tuber resistance to shear forces was laboratory tested using the same device in the penetration test after replacing the penetration probe by a slicing knife (Figure $4 \mathrm{~b}$ ). The test was conducted in order to examine the impact of soil compaction on the hardness of tubers' wall and their resistance to the unexpected cut or slicing that could occur during harvesting.

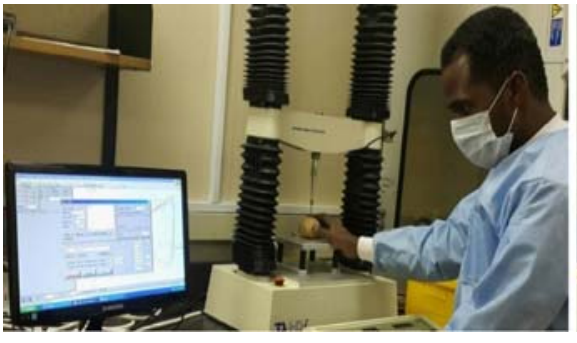

a.

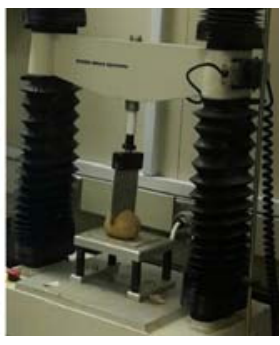

b.
Figure 4 Tests for potato tuber penetration (a) and shear forces (b)

\subsection{Statistical analysis of the results}

The collected data was subjected to the ANOVA statistical test to identify the significant treatments and/or the interaction effects by the ' $F$ test' using the SAS software program (SAS Systems for Windows, release 9.2, SAS Institute, Cary, NC). The mean separation between the significant treatments was also calculated by the Duncan's multiple range test.

\section{Results and discussion}

\subsection{Effect of soil compaction on the engineering properties of potato tubers}

Descriptive statistical results of tuber length $(L)$, width $(W)$, thickness $(T)$ and shape index $(I)$, along with associated standard 
deviation $(S D)$ and coefficient of variation $(C V)$ values, are presented in Table 1. Soil compaction variability was represented, across the study field, by three compaction levels, namely, the low level (C1) with compaction values of 1.2-1.9 $\mathrm{MPa}$, the medium level (C2) with compaction values of 2.0-2.3 $\mathrm{MPa}$ and the high compaction level (C3) with compaction values of 2.4-2.9 $\mathrm{MPa}$. Three potato tubers were randomly taken for each sampling point to measure the above mentioned main dimensions. Results revealed that the average length of potato tubers was higher in the areas of low compaction level. Values of the tuber shape index for the three compaction levels were all below 1.5, indicating that the tubers fell within the spherical shape category. This is in agreement with the study conducted by Ismail ${ }^{[28]}$, where he reported that the tuber shape of the studied potato variety (Spunta) was considered as spherical.

Table 1 Statistics of the tuber key dimensions and shape index

\begin{tabular}{|c|c|c|c|c|c|c|c|}
\hline Properties & $\mathrm{N}$ & Compaction level & Average & Max & Min & SD & $\mathrm{CV}$ \\
\hline \multirow{3}{*}{$\begin{array}{l}\text { Tuber } \\
\text { length } \\
/ \mathrm{mm}\end{array}$} & \multirow{3}{*}{120} & $\mathrm{C} 1$ & 94.5 & 127.9 & 76.4 & 17.1 & 18.10 \\
\hline & & $\mathrm{C} 2$ & 87.8 & 113.0 & 75.9 & 12.0 & 13.60 \\
\hline & & $\mathrm{C} 3$ & 87.6 & 111.1 & 75.0 & 11.9 & 13.60 \\
\hline \multirow{3}{*}{$\begin{array}{l}\text { Tuber } \\
\text { width } \\
/ \mathrm{mm}\end{array}$} & \multirow{3}{*}{120} & $\mathrm{C} 1$ & 76.8 & 100.0 & 64.4 & 12.7 & 16.50 \\
\hline & & $\mathrm{C} 2$ & 74.7 & 96.0 & 61.1 & 12.2 & 16.40 \\
\hline & & $\mathrm{C} 3$ & 70.8 & 94.0 & 57.2 & 11.2 & 15.80 \\
\hline \multirow{3}{*}{$\begin{array}{l}\text { Tuber } \\
\text { thickness } \\
\text { /mm }\end{array}$} & \multirow{3}{*}{120} & $\mathrm{C} 1$ & 66.4 & 96.0 & 84.0 & 15.4 & 23.10 \\
\hline & & $\mathrm{C} 2$ & 64.9 & 88.9 & 46.0 & 14.9 & 23.00 \\
\hline & & $\mathrm{C} 3$ & 61.8 & 85.0 & 46.0 & 14.1 & 22.8 \\
\hline \multirow{3}{*}{$\begin{array}{l}\text { Shape } \\
\text { index }\end{array}$} & \multirow{3}{*}{120} & $\mathrm{C} 1$ & 1.32 & 184 & 1.16 & 0.19 & 14.26 \\
\hline & & $\mathrm{C} 2$ & 1.28 & 1.44 & 1.14 & 0.12 & 9.19 \\
\hline & & $\mathrm{C} 3$ & 1.34 & 1.48 & 1.14 & 0.08 & 6.27 \\
\hline
\end{tabular}

Variability analysis was also conducted in order to examine the effect of soil compaction on the tuber key dimensions (length, width and thickness). The impact of soil compaction on the key tuber dimensions is shown in Figure 5.

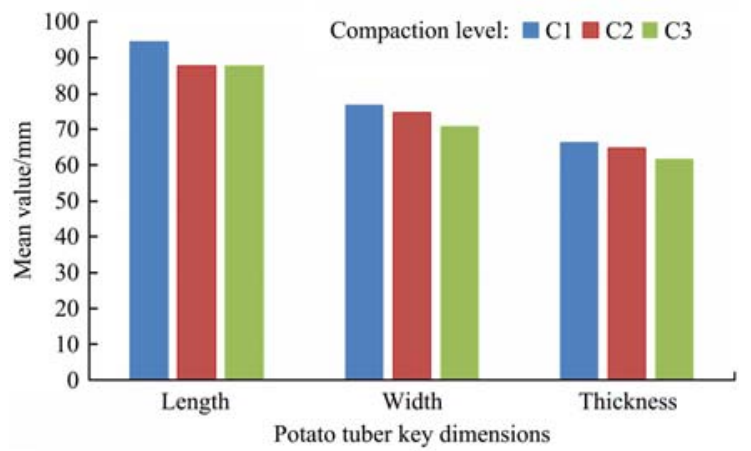

Figure 5 Impact of soil compaction on potato tuber key dimensions

ANOVA test was conducted in order to examine the tightness and significance of the relationship between soil compaction and the tuber key dimensions (Table 2). Results exhibited an inverse correlation between soil compaction and key tuber dimensions, with $R^{2}$ values of $77 \%, 97 \%$ and $96 \%$ for the tuber length, width and thickness, respectively. It was observed that low compaction areas produced tubers with the largest dimensions compared to other compaction levels. However, the ANOVA results indicated that there was no significant response of tuber key dimensions to the studied levels of soil compaction, with $p>F$ values of 0.3967 , 0.4833 and 0.7363 for tuber length, width and thickness, respectively. The obtained low probability of recording no significant response to the studied compaction levels can be related to other factors, as stated by Lizarazo et al. ${ }^{[31]}$ that variations in potato sizes and in chemical and physical compositions were determined by genetic factors, agricultural practices and climatic and soil conditions.

Table 2 ANOVA results for tuber dimensions at different soil compaction levels

\begin{tabular}{|c|c|c|c|c|c|c|c|}
\hline \multirow{2}{*}{\multicolumn{2}{|c|}{$\begin{array}{l}\text { Main dimensions } \\
\text { Statistical Analysis }\end{array}$}} & \multicolumn{2}{|c|}{ Length/mm } & \multicolumn{2}{|c|}{ Width/mm } & \multicolumn{2}{|c|}{ Thickness/mm } \\
\hline & & Mean & $p>F$ & Mean & $p>F$ & Mean & $p>F$ \\
\hline \multirow{3}{*}{$\begin{array}{l}\text { Compaction } \\
\text { levels }\end{array}$} & Low (C1) & $94.492^{\text {aa }}$ & \multirow{3}{*}{0.3967} & $76.769^{\text {aa }}$ & \multirow{3}{*}{0.4833} & $66.442^{\text {aa }}$ & \multirow{3}{*}{0.7363} \\
\hline & Medium (C2) & $87.828^{\mathrm{aa}}$ & & $74.672^{\text {aa }}$ & & $64.911^{\text {aa }}$ & \\
\hline & High (C3) & $87.619^{\mathrm{a}}$ & & $70.844^{\mathrm{a}}$ & & $61.781^{\mathrm{a}}$ & \\
\hline
\end{tabular}

Note: $p<0.05$.

\subsection{Tubers resistance to shear, compression and penetration forces}

The impact of soil compaction on the physical properties of the collected tuber samples was investigated. The investigated properties included the tuber resistance to shear, compression and penetration forces. ANOVA test was employed for the analysis in order to study the effect of the spatial variation in soil compaction on the physical structure of potato tubers. The analyzed results (Table 3) basically showed that there was no significant change, as a result of compaction variability, on the potato tuber compression and shear forces with $p>F$ values of 0.5536 and 0.3192 for compression and shear forces, respectively. However, for the tuber penetration resistance, an indication of high significant influence of soil compaction was observed ( $p>F=0.0012$ ). In fact, no clear cause was identified, but these tests may confirm the complexity of potato tissues and how their mechanical properties changed during storage. This is coincident with the results reported by Pang and Scanlon ${ }^{[32]}$ that both small-strain oscillatory shear and uniaxial compression indicated that potato parenchyma is anisotropic in nature.
Table 3 ANOVA results for tuber physical properties at different soil compaction levels

\begin{tabular}{|c|c|c|c|c|c|}
\hline \multirow{2}{*}{\multicolumn{2}{|c|}{ physical test }} & \multirow{2}{*}{$\begin{array}{l}\text { Statistical } \\
\text { analysis }\end{array}$} & \multicolumn{3}{|c|}{ Compaction levels } \\
\hline & & & Low (C1) & Medium (C2) & High (C3) \\
\hline \multirow{4}{*}{$\begin{array}{c}\text { Compression } \\
\text { test }\end{array}$} & \multirow{2}{*}{$\begin{array}{l}\text { Bio yield } \\
\text { force/N }\end{array}$} & Mean & $1250.97^{\text {aa }}$ & $1360.75^{\text {aa }}$ & $1246.56^{\mathrm{a}}$ \\
\hline & & $p>F$ & & 0.5536 & \\
\hline & \multirow{2}{*}{ Work $/ \mathrm{N} \cdot \mathrm{m}$} & Mean & $20.80^{\mathrm{a}}$ & $23.56^{\text {aa }}$ & $21.20^{\mathrm{aa}}$ \\
\hline & & $p>F$ & & 0.3655 & \\
\hline \multirow{4}{*}{$\begin{array}{l}\text { Penetration } \\
\text { test }\end{array}$} & $\begin{array}{l}\text { Maximum } \\
\text { Penetration }\end{array}$ & Mean & $9.99^{\mathrm{a}}$ & $10.82^{\text {aa }}$ & $9.09^{b}$ \\
\hline & Force/N & $p>F$ & & 0.0012 & \\
\hline & \multirow{2}{*}{ Work/N·m } & Mean & $0.09^{\mathrm{a}}$ & $0.09^{\mathrm{aa}}$ & $0.07^{\mathrm{b}}$ \\
\hline & & $p>F$ & & 0.0019 & \\
\hline \multirow{4}{*}{ Shear test } & $\begin{array}{l}\text { Maximum } \\
\text { Shear }\end{array}$ & Mean & $158.95^{\mathrm{a}}$ & $168.66^{\mathrm{aa}}$ & $204.09^{\text {aa }}$ \\
\hline & Force/N & $p>F$ & & 0.3192 & \\
\hline & \multirow{2}{*}{ Work $/ \mathrm{kg} \cdot \mathrm{mm}$} & Mean & $5.015^{\mathrm{b}}$ & $5.50^{\mathrm{abb}}$ & $5.94^{\text {aa }}$ \\
\hline & & $p>F$ & & 0.0516 & \\
\hline
\end{tabular}

Note: $p<0.05$ 


\section{Conclusions}

A field study was carried out in order to investigate the impact of the spatial variation of soil compaction on physical properties of potato tubers. Three compaction levels were included in the study which encompassed low compaction level of 1.2-1.9 MPa, medium compaction level of 2.0-2.3 MPa and high compaction level of 2.4-2.9 MPa. Specific conclusions of the study can be listed as the following:

The engineering tuber properties (tuber key dimensions) were found to be spatially correlated with the different soil compaction levels. However, the tuber shape index values of $<1.5$ under all compaction levels indicated that the shape of the studied potato variety was considered as spherical and independent from compaction.

Tuber key dimensions were found to be inversely correlated to soil compaction with $R^{2}$ values of $77 \%, 97 \%$ and $96 \%$ for tuber length, width and thickness, respectively. However, the ANOVA results indicated that there was no significant response of tuber key dimensions to soil compaction, with $p>F$ values of $0.3967,0.4833$ and 0.7363 for tuber length, width and thickness, respectively.

Within the soil compaction levels included in the study, the soil compaction was found to have no significant effect on potato tuber compression and shear forces, with $p>F$ values of 0.5536 and 0.3192 for compression and shear forces, respectively. However, a high significant influence of soil compaction on tuber penetration resistance was observed $(p>F=0.0012)$.

Finally, future studies were recommended on the impact of genetic diversity on changes of its physicochemical properties corresponding to spatial changes in soil compaction.

\section{Acknowledgements}

The authors are grateful to the Deanship of Scientific Research, King Saud University for funding this study through the Vice Deanship of Scientific Research Chairs. The extensive cooperation and support extended by the staff in the Saudi Agricultural Development Company (INMA) farm in carrying out the field research work are gratefully acknowledged.

\section{[References]}

[1] Hamza M A, Anderson W K. Soil compaction in cropping systems: A review of the nature, causes and possible solutions. Soil and tillage research, 2005; 82(2): 121-145.

[2] Dees M W, Wanner L A. In search of better management of potato common scab. Potato Research, 2012; 55(3-4): 249-268.

[3] Bravo C, Andreu E. Propiedades fisicas y produccion de maiz (Zea mays L.) en un Alfisol del estado Guarico, Venezuela, bajo dos sistemas de labranza. Venesuelos, 2011; 3(2): 62-68.

[4] Marques J D S, Siqueira L A, Camargo D D B, Teixeira V Barron, Torrent J. Magnetic susceptibility and diffuse reflectance spectroscopy to characterize the spatial variability of soil properties in a Brazilian Haplustalf. Geoderma, 2014; 219-220: 63-71. doi: 10.1016/ j.geoderma.2013.12.007

[5] Zucco G, Brocca L, Moramarco T, Morbidelli R. Influence of land use on soil moisture spatial-temporal variability and monitoring. Journal of Hydrology, 2014; 516: 193-199. doi: 10.1016/j. jhydrol.2014.01.043.

[6] Rojas A, Ibarra J. Efectos del uso del suelo sobre algunas propiedades quimicas y fisicas, considerando suelos bajo cobertura de bosque y suelos bajo uso agricola. Invest. Agr., 2013; 8(1): 10-14.

[7] Cruz J S, Júnior R N A, Matias S S R, Camacho-Tamayo J H. Spatial variability of an Alfisol cultivated with sugarcane. Ciencia E
Investigación Agraria, 2011; 38(1): 155-164.

[8] Barik K, Aksakal E L, Islam K R, Sari S, Angin I. Spatial variability in soil compaction properties associated with field traffic operations. Catena 2014; 120: 122-133.

[9] Dalvand M. Physical properties of potato tubers cv. analytic cultivated in Iran. Vegetable Crops Research Bulletin, 2011; 74: 117-128.

[10] Peleg K. Produce handling, packaging, and distribution. The AVI Publishing Company. Inc. Westport, Connecticut, 1985; pp.5-95.

[11] Mohsenin N N. Physical Properties of Plant and Animal Materials. Gordon and Breach Science Publishers, 1986; pp.20-89.

[12] Sadowska J, Fornal J, Zgórska K. The distribution of mechanical resistance in potato tuber tissues. Postharvest biology and technology, 2008; 48(1): 70-76.

[13] Cubero S. Erratum to: Advances in machine vision applications for automatic inspection and quality evaluation of fruits and vegetables. Food and Bioprocess Technology, 2011; 4-5: 829-830.

[14] Hahn F, Sanchez S. Carrot volume evaluation using imaging algorithms. Journal of Agricultural Engineering Research, 2000; 75(3): 243-249.

[15] Mitchell P D. Pear fruit growth and the use of diameter to estimate fruit volume and weight. Horticultural Science, 1986; 21(4): 1003-1005.

[16] Ngouajio M, Kirk W, Goldy R. A simple model for rapid and nondestructive estimation of bell pepper fruit volume. Hort. Science, 2003; 38(4): 509-511.

[17] Safa M, Khazaei J. Determining and modeling some physical proper-ties of pomegranate fruits of Saveh area related to peeling and packaging. In: International Congress on Information Technology in Agriculture, Food and Environment, Izmir, Turkey, October 7-10, 2003; pp.331-337.

[18] Petelkau H, Gatke R, Dannowski M, Seidel M. Relationship between bulk density of soil and crop production. Rep. Soil Science Res. Center. Muncheberg, East Germany, 1985.

[19] Kahnt G, Hijazi L A, Rao M. Effect of homogeneous soil compaction on shoot and root growth of field bean soybean. Zeitschriff fur acker und Pflanzenbau, 1986; 157: 105-113.

[20] Iler G S, Stevenson C K. The effects of soil compaction on the production of processing vegetables and field crops: A review. Queen's Printer for Ontario, 1991. http://hdl.handle.net/10214/14039.

[21] Boone F R, de Smet L A H, van Loon C D. The effect of ploughman in marine loam soils on potato growth I. Physical properties and rooting patterns. Potato Res, 1985; 28: 295-314.

[22] Castillo S R, Dowdy R H, Bradford J M, Larson W E. Effects of applied mechanical stress on plant growth and nutrient uptake. Agron. J, 1982; 74 526-529.

[23] Laza M, Scanlon M G, Mazza G. The effect of tuber pre-heating temperature and storage time on mechanical properties of potatoes. Food Research International, 2001; 34: 659-667.

[24] Alvarez M D, Canet W. Storage time effect on the rheology of refrigerated potato tissue (cv. Monalisa). European Food Research and Technology, 2000; 212(1): 48-56.

[25] Elhag M. Evaluation of different soil salinity mapping using remote sensing techniques in arid ecosystems, Saudi Arabia. Journal of Sensors. Faso. International Journal of Remote Sensing, 2016; 14(8): 1495-1515.

[26] Eijkelkamp. Equipment for Soil Research. Eijkelkamp Company, The Netherlands, 1990; 240p.

[27] Tabatabaeefar A. Size and shape of potato tubers. Agrophysics, 2002; 16: 301-305.

[28] Ismail Z E. Some of the physio-mechanical properties for potato planters. Journal of Agricultural Science, Mansoura University, 1988; 13(4): 2259-2270.

[29] Gamea G R, El-Maksoud A, El-Gawad A. Physical characteristics and chemical properties of potato tubers under different storage systems. Misr Journal of Agricultural Engineering, 2009; 26: 385-408.

[30] ASAE standard. Compression test of food materials of convex shape. 8 p. American Society of Agricultural Engineers (ASAE), St. Joseph, Michigan, USA, 2002.

[31] Patricia L H S, Gonzalo H R G, Felipe R L. Physicochemical and morphological characterization of potato starch (Solanum tuberosum L.) As raw material for the purpose of obtaining bioethanol. Agronomía Colombiana, 2015; 33(2): 244-252.

[32] Pang C H, Scanlon M G. Mechanical properties of the parenchyma of potato (Solanum tuberosum cv. Russet Burbank). Canadian Journal of Botany, 1996; 74(6): 859-869. 